\title{
Gravel bars in low-sinuosity streams (Permian and Triassic, central Spain)
}

\author{
AMPARO RAMOS* and ALFONSO SOPEÑA $\dagger$ \\ * Departamento de Estratigrafia, Facultad de Ciencias Geológicas, Universidad Complutense, Madrid 3 and \\ $\dagger$ Instituto de Geología Económica C.S.I.C., Madrid 3, Spain
}

\begin{abstract}
The Buntsandstein sequence of the central area of Spain ranges from a variety of fluvial facies, low in the succession, to tidal mudstones and carbonates in the youngest and most eastern areas. This paper is restricted to the conglomerates in the lowest part of the fluvial sequence. These were deposited in bar and channel systems dominated by gravelly, low-sinuosity braided streams. Their distribution reflects both the pre-existing topography and synsedimentary tectonic movements.

Six main facies have been distinguished (in order of decreasing abundance): sheets of massive conglomerates, channel-fill conglomerates, coarse-medium sandstones, lateral accretion conglomerates. tabular cross-stratified conglomerates, fine-grained sediments.

Sheets of gravels, formed as longitudinal bars, were by far the major feature of sediment accumulation. Units of lateral accretion, if not very frequent, are quite important as they probably represent modifications of bars during waning stage.

Two big cycles may be seen in these conglomerates. They correspond to different physiographic models. The lower cycle was mainly formed by smaller channels and bars than was the upper cycle. The lower cycle is mainly formed by channel deposits, whilst in contrast, the upper cycle is mainly made up of longitudinal bars.

The change in sedimentation may be due to tectonic movements that occurred in the basin during Buntsandstein deposition.
\end{abstract}

\section{INTRODUCTION}

The sedimentation of gravelly streams is difficult to study, not only in the ancient record, but also at the present day. The direct observation of clast movement and bedform evolution is particularly difficult because the movement and evolution take place during flood stage with strong currents and normally turbid waters. Moreover, the necessary flow conditions cannot be achieved experimentally in laboratory flumes and it is quite difficult to construct facies models to compare with ancient sediment sequences.

In contrast, grain size, the shapes of bedforms, their relationships and their organization, can sometimes be studied quite well in ancient gravelly deposits These sediments have very complex geometries as has been pointed out by Bluck $(1976,1979)$, using both ancient

0141-3600/83/0106-0301 \$02.00

(C) 1983 International Association of Sedimentologists and present-day examples. When working in ancient sediments it is difficult to isolate single depositional events. Very different geometrical bodies may be closely related or they may even belong to a single event; in contrast, similar geometries may have different causes.

A two-stage analysis is presented here as part of a study of 'Buntsandstein' conglomerates in the Iberian Ranges (Central Spain). First, the main facies are described, according to their geometry and internal structure in cross-section. Secondly, a general model is constructed and its significance assessed.

\section{GEOLOGICAL FRAMEWORK}

The 'Buntsandstein' sediments in the study area (Fig. 1) are mainly fluviatile conglomerates and 


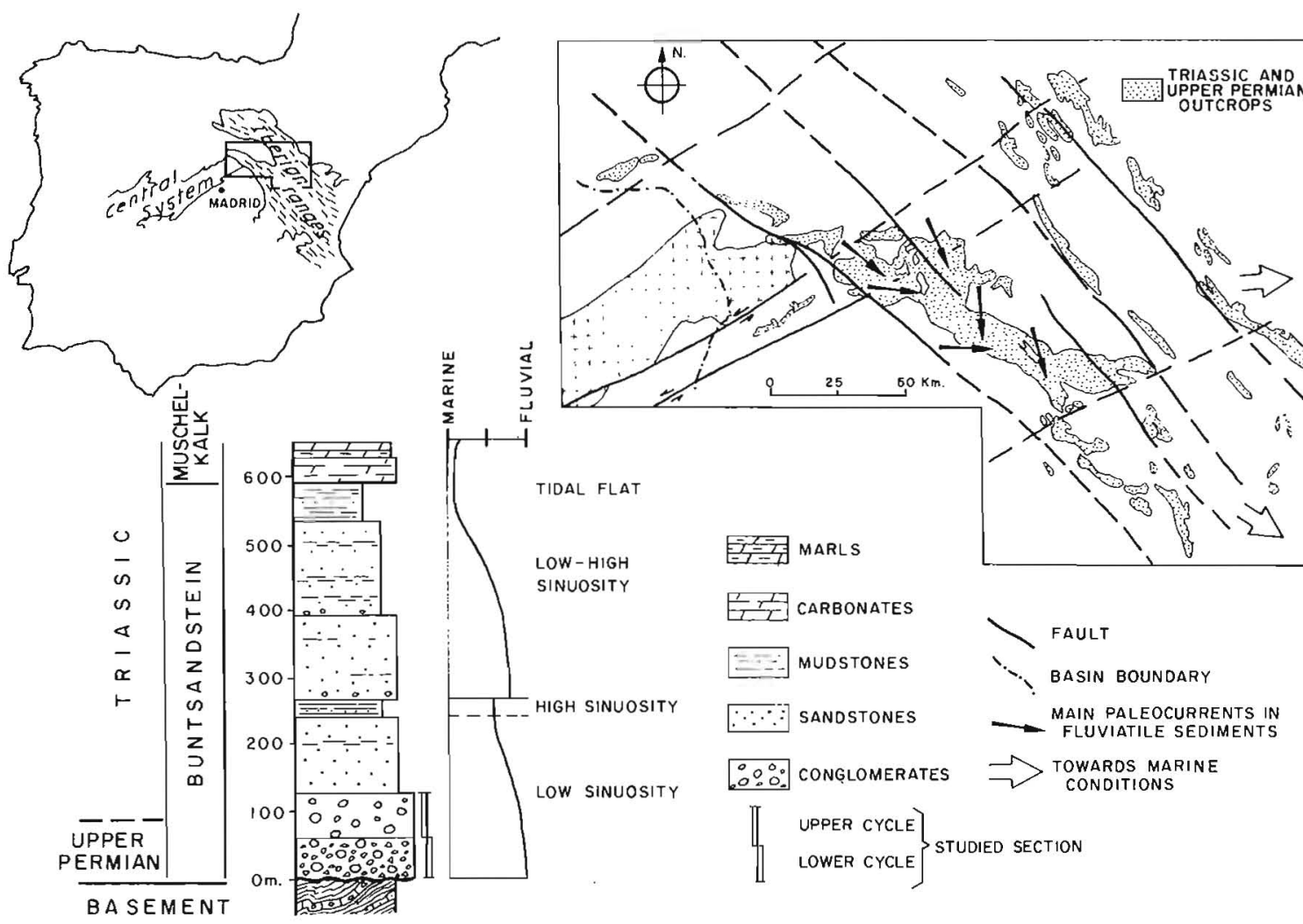

Fig. 1. Location maps and generalized stratigraphic sequence.

sandstones. They form the base of a complete and continuous sequence, from fluviatile sediments below to clastic tidal sediments and carbonate tidal sediments ('Muschelkalk') above. These 'Muschelkalk' facies were the westernmost carbonate sediments of the Tethys sea.

The thickness of the 'Buntsandstein' varies greatly in central Spain and may reach up to $800 \mathrm{~m}$ near the Central System. It can be divided into several lithostratigraphic units, whose ages range from Upper Permian (Thuringian) to Middle Triassic (Ladinian) (Ramos, 1979; Sopeña, 1979). The 'Buntsandstein' is mainly composed of sandstone (Fig. I) but, low in the sequence, there are some conglomerates (this study), mudstones, and a few caliche deposits.

These sediments accumulated in a tectonically active basin. Important strike-slip faults with a NW-SE trend (Fig. 1) developed towards the end of Hercynian movements. Later vertical movements produced a topography of uplifted blocks and basins which filled with 'Buntsandstein' fluviatile sediments.
The fact that some of these movements occurred during the sedimentation is proved by the observation that some faults cut lower 'Buntsandstein' sediments and were covered by upper 'Buntsandstein' sediments.

The lower conglomerates always rest unconformably on a basement of Hercynian metamorphic or Lower Permian sedimentary rocks (Virgili et al., 1980). Their thickness varies from 70 to $180 \mathrm{~m}$. The palaeorelief at the beginning of 'Buntsandstein' probably produced this variation.

The main fluviatile palaeocurrents across the basin were from north to south, or from NW to SE, but there are some local deviations, probably due to small alluvial fans extending from local sources.

\section{FACIES DESCRIPTION}

This study is restricted to lower Buntsandstein conglomerates (Fig. 1). More than 40 sections have 


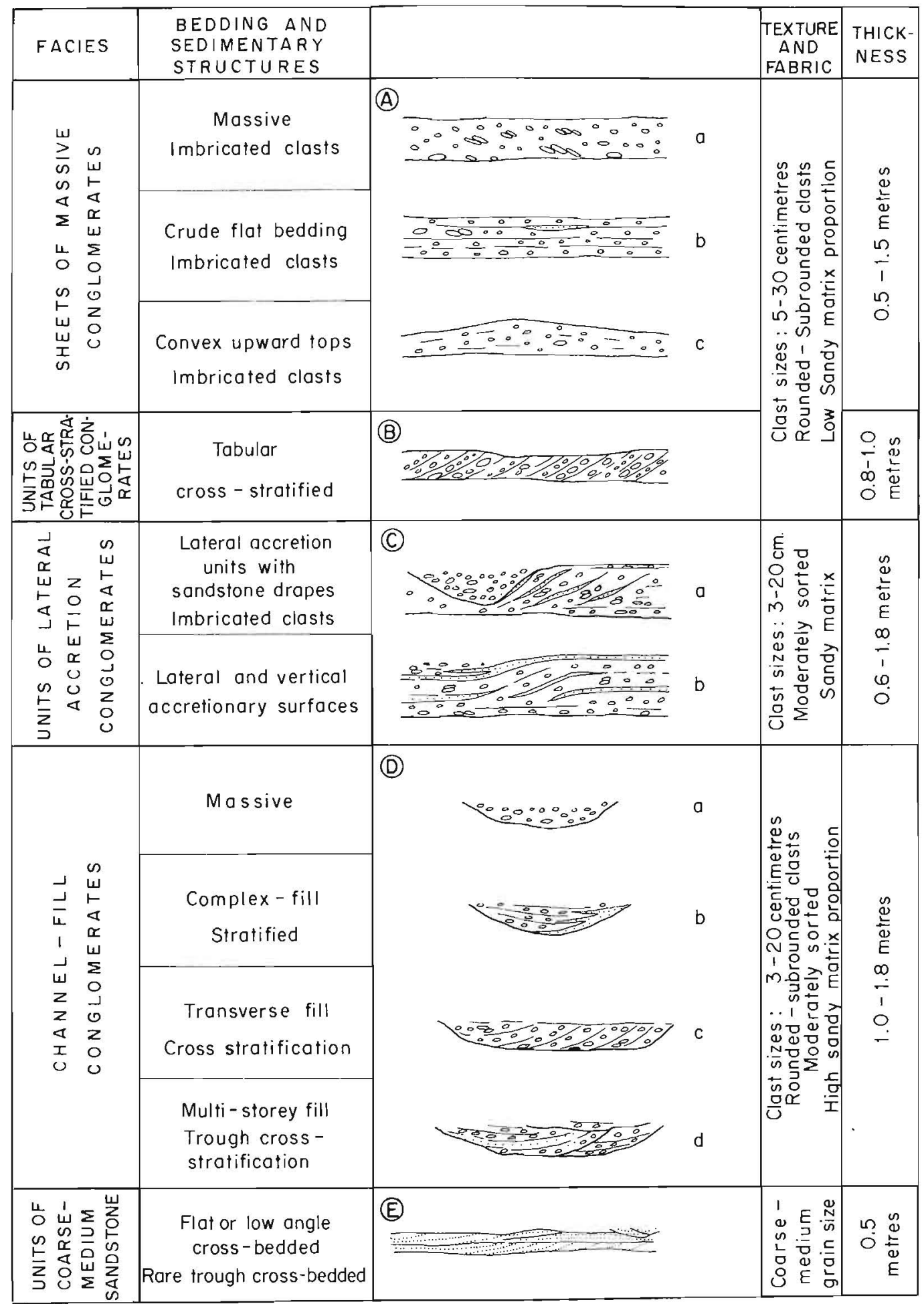

Fig. 2. Characteristics of depositional facies types. 
been studied and six main facies have been distinguished (Fig. 2); sheets of massive conglomerates, tabular cross-stratified conglomerates, lateral accretion conglomerates, channel-fill conglomerates, coarse-medium sandstones and fine-grained sediments. Sheets of massive conglomerates, channelfill conglomerates and coarse-medium sandstones are (in that order) the most frequent facies, with only minor occurrences of the other facies. Conglomerates are by far the most important lithology ( $>90 \%$ ), with only minor amounts of sandstones and mudstones $(<10 \%)$.

\section{Sheets of massive conglomerates}

Extensive sheets of conglomerate (Fig. 2A) are the diagnostic features of these sediments. They mainly consist of quartzitic clasts which are rounded or subrounded or, rarely, subangular. The clasts are generally in contact and have very characteristic dissolution marks, where part of one clast has been pressed into another. A sandy matrix may be present, filling voids. Clast sizes range from 5 to $15 \mathrm{~cm}$, sometimes reaching between 20 and $30 \mathrm{~cm}$.

The sheets range from 0.5 to $1.5 \mathrm{~m}$ thick and extend tens of metres laterally. Internally these are either massive or show a crude flat bedding (Fig. 3). Flat stratification is sometimes due to alternations of beds of different clast size. The tops of these beds may be convex upward. The convexity is normally very low, which makes it difficult to recognize in small outcrops. The clasts may be imbricate (Fig. 4).

Small massive sheets of conglomerate may act as the core for lateral accretion conglomerates (Fig. 2C).

In vertical sequences composed entirely of conglomerate, individual units may be distinguished by the

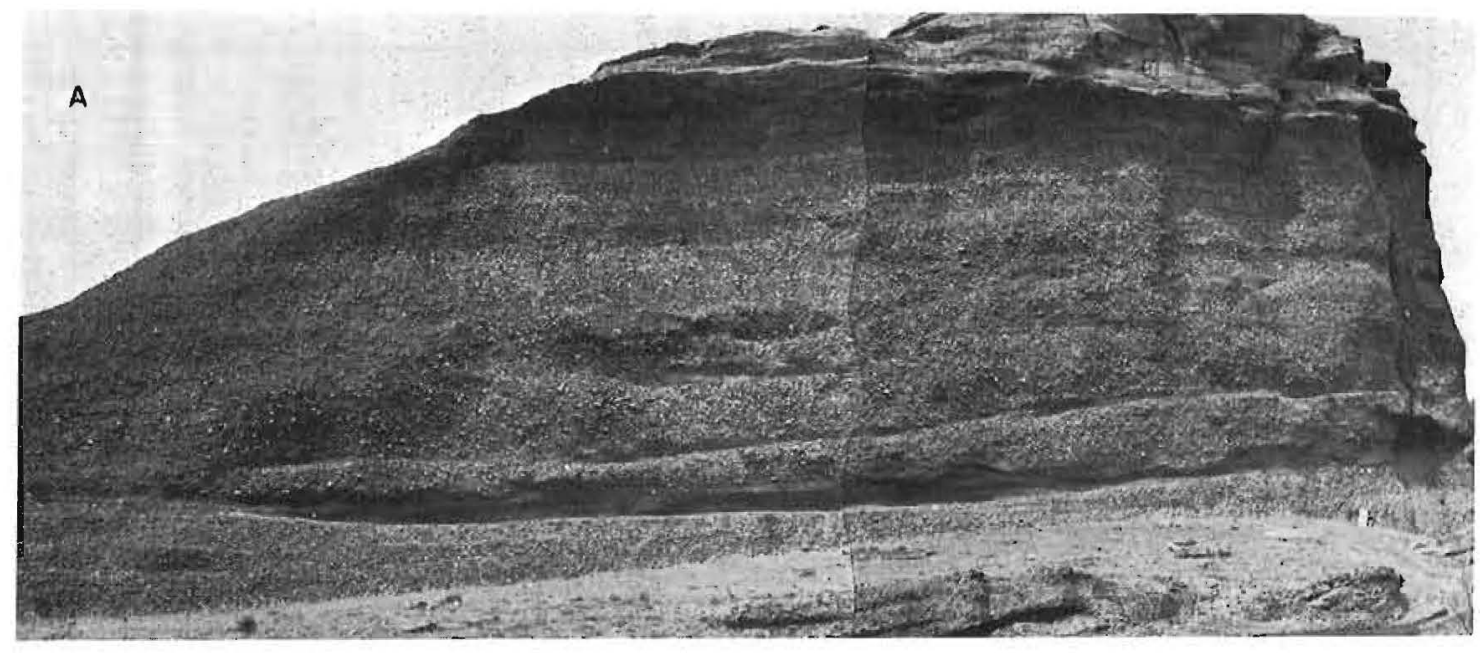

B

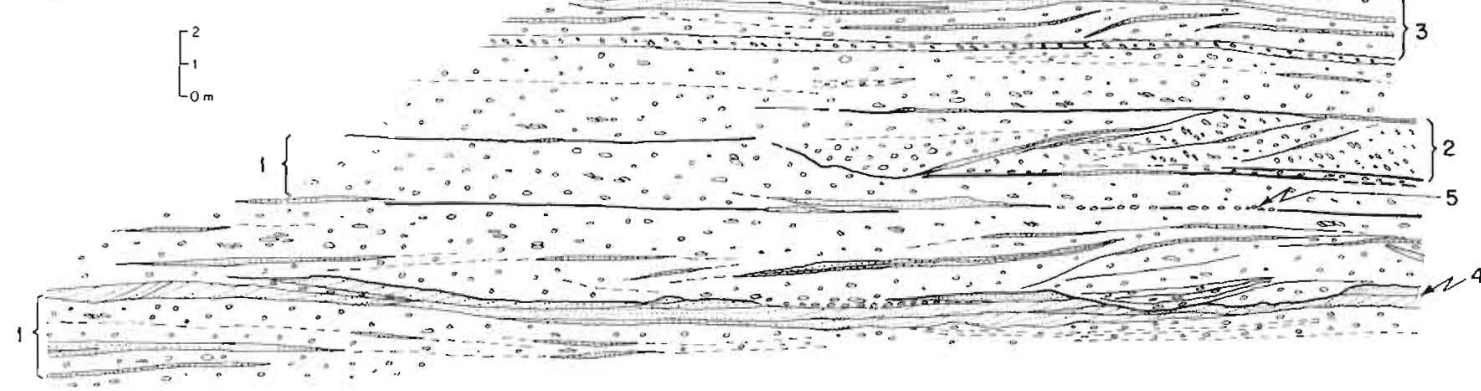

Fig. 3. (A) Upper conglomerate. Hombrados (Guadalajara). Long. $1^{\circ} 41^{\prime} 7^{\prime \prime}$, lat. $43^{\circ} 4^{\prime}$. (B) Field sketch from (A). (1) Massive or crude flat-bedding sheet (longitudinal bar). (2) Units of lateral accretion conglomerate with sandstone drapes. They pass laterally into channel filled with massive gravels. (3) Units of lateral and vertical accretion conglomerate with scoured top. (4) Flat-bedded sandstone. (5) Clast pavement between two longitudinal bars. 


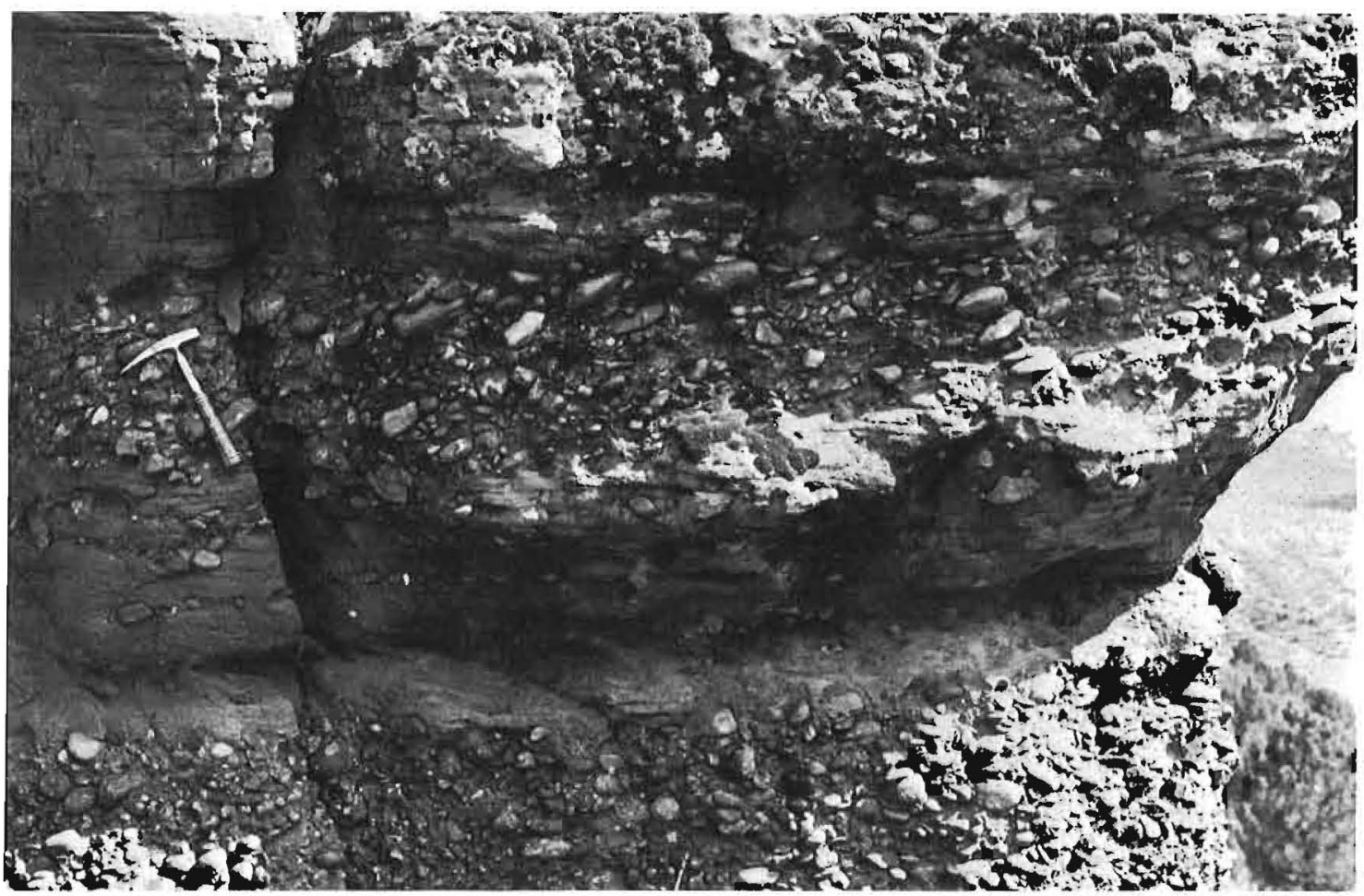

Fig. 4. Alternations of sandstone and gravel units with imbricated clasts. Flow was from left 10 right. Rillo de Gallo (Guadalajara). Long. $1^{\circ} 55^{\prime} 02^{\prime \prime}$, la1. $40^{\circ} 53^{\prime} 56^{\prime \prime}$.

scour or interruption surfaces between them, and sometimes by thin sandstone sheets (less than $20 \mathrm{~cm}$ thick) on top of the conglomerate sheets (Fig. 5A).

\section{Units of tabular cross-stratified conglomerate}

These conglomerate units (Fig. 2B) are normally less than $1 \mathrm{~m}$ thick and up to several metres in lateral extent (Fig. 5B). The foreset dips are quite constant, from $15^{\circ}$ to $20^{\circ}$. These conglomerates comprise clasts of various sizes, ranging from coarse sand to cobbles and boulders. They have flat bases, with foresets tangential to the lower bounding surfaces, and scoured tops.

Tabular cross-stratified conglomerates are sometimes associated with channels.

\section{Units of lateral accretion conglomerate}

These conglomerates (Fig. 2C) have flat and sometimes scoured bases. Occasionally, there may be gravel lags at their bases. The tops of units are frequently flat or sometimes convex upward. They range in thickness from 0.6 to $1.8 \mathrm{~m}$, and are generally less than $30 \mathrm{~m}$ long.

Internal surfaces dipping gently (between $8^{\circ}$ and $15^{\circ}$ ) can be seen inside these units. They are quite distinctive because they normally have a thin sandstone drape, some centimetres thick. The surfaces grew both laterally and vertically (Figs 3 and 5A), lateral growth being by far the most important. Imbricated clasts occur between the lateral accretion surfaces. When imbrication can be measured, the directional trend of the clast long axes deviates greatly from the direction of accretion of lateral accretionary surfaces. The thickness between the surfaces ranges from 20 to $70 \mathrm{~cm}$ with important changes in clast size, sometimes pebble, cobble and granule levels alternating.

These conglomerates sometimes pass laterally into massively or crudely stratified conglomerate units of convex-upward shape, that formed a core or nucleus on which the lateral accretion took place. They may also pass laterally into channels filled with gravels (Fig. 3). 

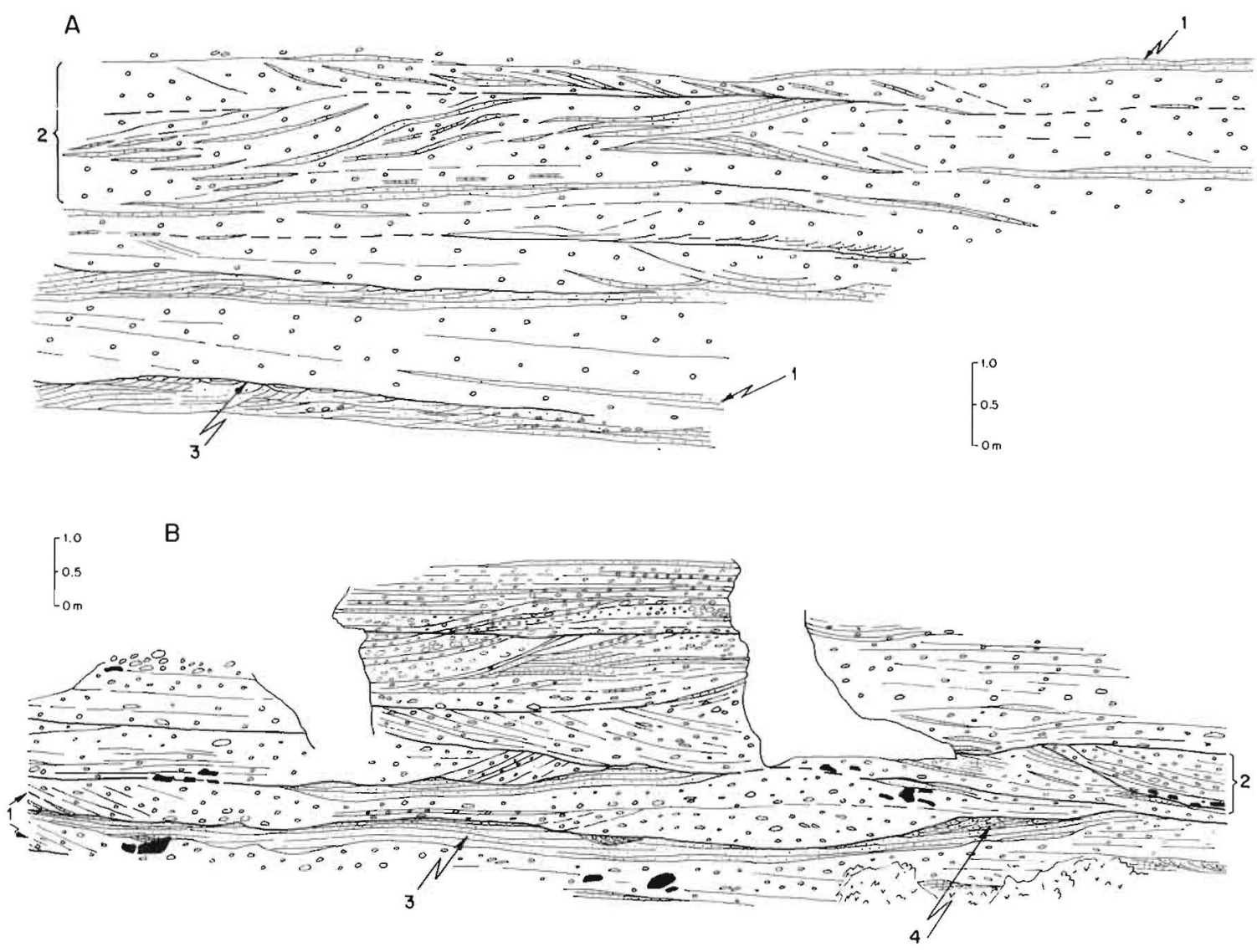

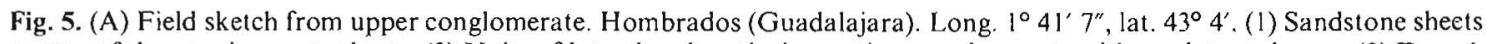
on top of the conglomerate sheets. (2) Units of lateral and vertical accretion conglomerate with sandstone drapes. (3) Trough cross-bedded sandstone. (B) Field sketch from lower conglomerate. Hombrados (Guadalajar). Long. $1^{\circ} 41^{\prime} 7^{\prime \prime}$, lat. 43 4'. (1) Tabular units of planar cross-stratified conglomerate (transverse bar). (2) Channel fill consisting of stratified conglomerates. (3) Flat-bedded sandstone. (4) Trough cross-bedded sandstone on top of flat-bedded sandstone.

\section{Channel-fill conglomerates}

These range from 1 to $1.80 \mathrm{~m}$ thick and from 7 to $10 \mathrm{~m}$ across (Fig. 2D). They are mainly of gravel, with a higher proportion of sandy matrix than is found in lateral accretion deposits.

The channel fills may consist of massive accumulations of pebbles and cobbles, or of stratified gravels, sandy gravels or sandstones (Figs 3 and 5B). Sometimes a complex or multi-storey fill may contain gravels passing up or laterally into sandy gravels and sandstones (Figs 6 and 7). Trough cross-stratified gravels, or gravelly sandstones, may also fill the channels (Figs 6 and 7), some channels have a transverse fill consisting of cross-stratified gravels (Figs 6 and 7), some have a major scoured base, lined with mud or sandstone intraclasts, up to $2 \mathrm{~m}$ long. Mud or sandstone cobbles may be incorporated in cross-stratified channel fills.

\section{Units of coarse-medium sandstone}

They form thin units (normally less than $0.5 \mathrm{~m}$ thick) (Fig. 2E). They extend laterally from a couple of metres to several tens of metres (Figs 3 and 5B). They are a feature of all the different conglomerate facies. They have flat bases or are moulded over the beds underneath. Their tops have normally been scoured (Fig. 3).

Trough cross-bedded sandstones sometimes occur on top of low-angle or flat-bedded sandstones (Fig $5 \mathrm{~A}, \mathrm{~B})$. 


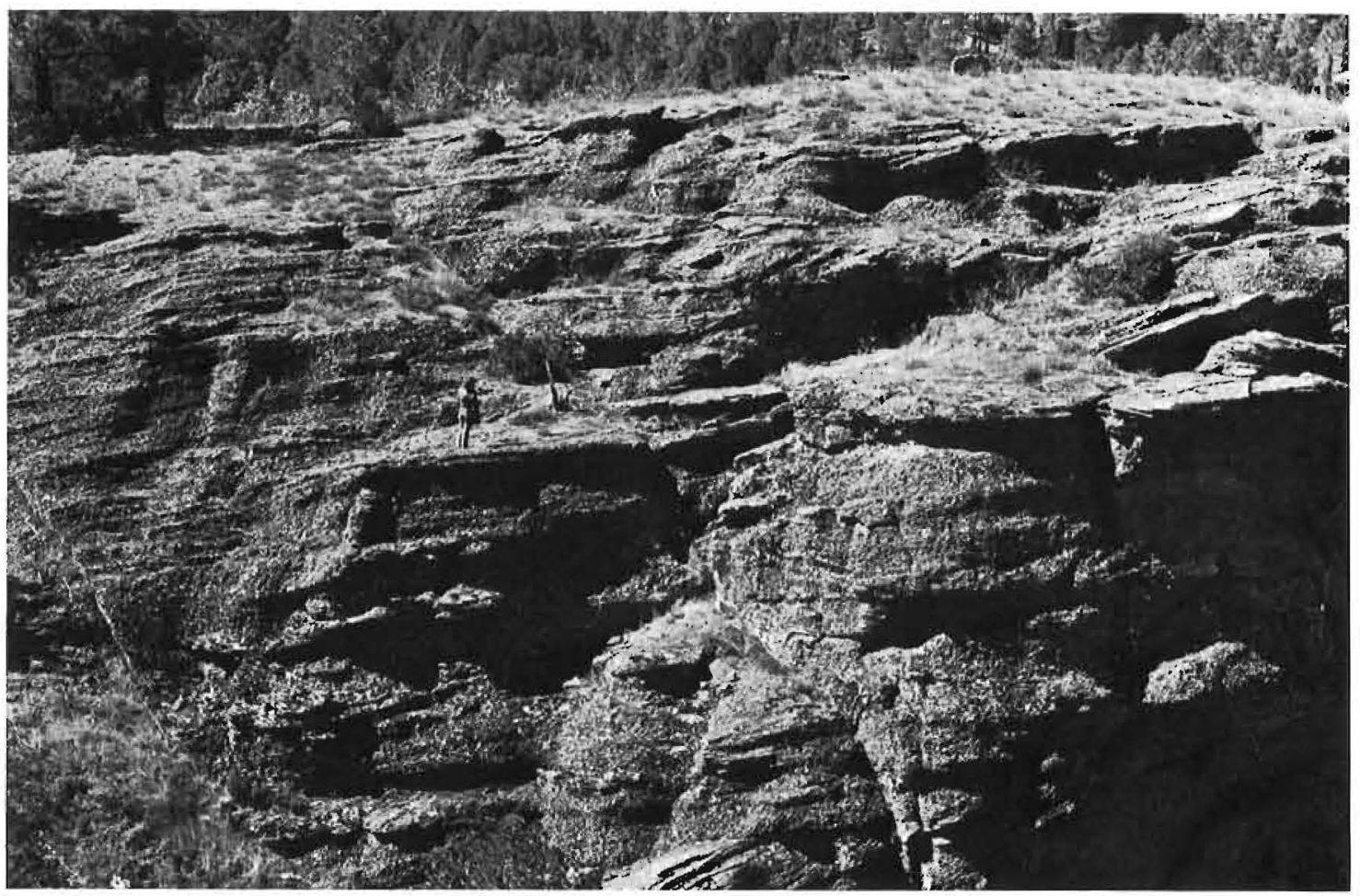

Fig. 6. Lower conglomerate. Rio Arandilla (Guadalajara). Long. $2^{\circ} 5^{\prime} 48^{\prime \prime}$, lat. $40^{\circ} 53^{\prime} 48^{\prime \prime}$.

Units of fine-grained sediment

Thin muddy sandstone beds, sometimes with bioturbation, are a rare feature of these sediments. Mudstone and fine-grained sandstone clasts may also be present above the major scoured surfaces (Fig. 5B). These clasts are usually angular in shape, ranging from a few centimetres to more than $1 \mathrm{~m}$ in size.

\section{FACIES RELATIONSHIPS AND ASSOCIATIONS}

Two main groups of facies may be distinguished according to their frequency. Sheets of massive conglomerates $(\simeq 40 \%)$, channel fill conglomerates $(\simeq 25 \%)$ and coarse-medium sandstones $(\simeq 20 \%)$ are the most important groups, with only minor amounts of the other facies: lateral accretion conglomerates $(\simeq 8 \%)$, tabular cross-stratified conglomerates $(5 \%)$ and fine-grained sediments $(\simeq 2 \%)$.

Sheets of massive conglomerates (Fig. 3), which are the most frequent facies, may be associated with nearly all the other facies. They may be alternating with one another, with some thin sand horizons between them that help to separate them. When such sandstone beds do not exist, it may be quite difficult to separate them, because interruption by scour surfaces is not always apparent. Sheets of massive conglomerates may pass laterally into lateral accretion conglomerates. These lateral accretion conglomerates do not have any important lateral extent (only a few metres) (Fig. 3). Lateral accretion conglomerates are normally associated with sheets of massive conglomerates but they are much less frequent.

Channel-fill conglomerates are also quite important in our sediments. We have normally a multi-storey pattern of channels which cut into each other both vertically and laterally (Figs 6 and 7). They may also be associated with sheets of massive conglomerates and/or lateral accretion conglomerates. So the lateral relationships: sheets of massive conglomerates-lateral accretion conglomerates-channel fill conglomerates, or sheets of massive conglomerates-channel-fill conglomerates are not rare (Fig. 3).

Two different subfacies may be distinguished in the coarse-medium sandstone facies: thin and short drapes of sand and extensive sheets which are quite 


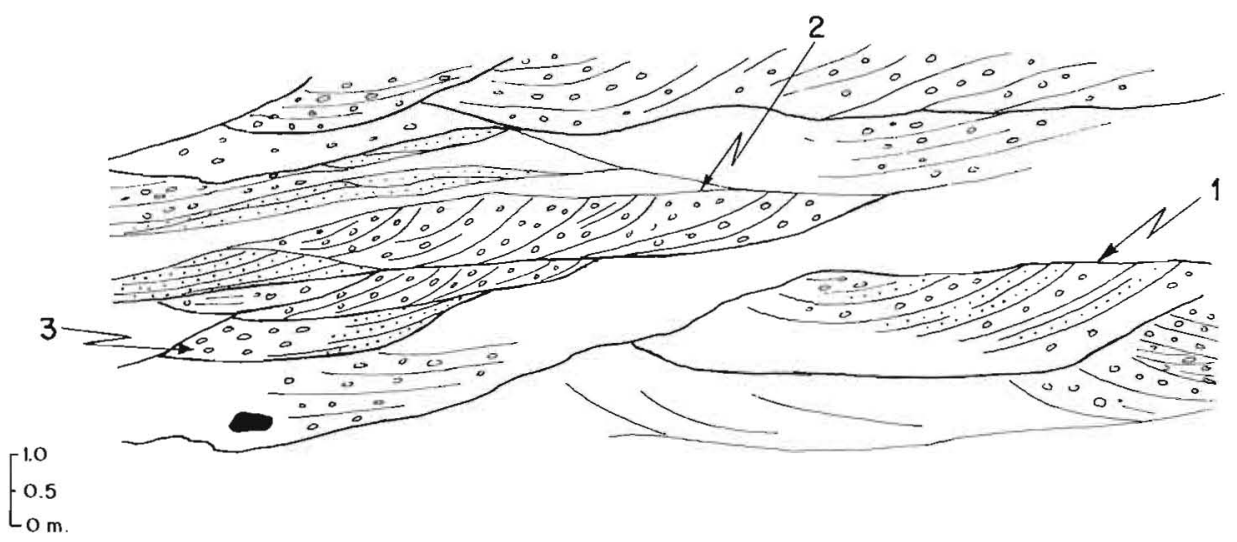

Fig. 7. Field sketch from Fig. 6. (1) Channel fill consisting of trough cross-stratified gravelly sandstones. (2) Channel with a transverse fill consisting of cross-stratified gravels. (3) Channel fill consisting of gravels passing laterally into sandsiones.

continuous laterally. The former may be associated with all the other facies. They may be on top of sheets of massive conglomerates, as channel fills or between lateral accretion surfaces. The second subfacies may cover extensive areas and may occur above or below channel-fill conglomerates, sheets of massive conglomerates, or even lateral accretion conglomerates or tabular cross-stratified conglomerates (Figs 3 and 5).

Tabular cross-stratified conglomerates, which are quite rare here, may occur in association with channels.

Finally, the few fine-grained sediments are normally big blocks, always associated with channels or with big scoured surfaces (Fig. 5B).

\section{INTERPRETATION}

In our area, sheets of gravels (Fig. 2A) were the major features of sediment accumulation. We think that they formed as longitudinal bars (Fig. 3), similar to those described by many authors in modern gravelly braided streams and their inferred ancient equivalents (Ore, 1964; Williams \& Rust, 1969 ; Smith, 1974; Rust, 1978). Convex-upward surfaces characteristic of these bars have been clearly preserved in many bars in our area.

Sheets of gravel do not normally represent a single depositional event and this is proved by multiple scoured surfaces and thin sandstone beds within them (Fig. 5A).

According to many studies (Leopold \& Wolman, 1957; Smith, 1974; Hein \& Walker, 1977), longitudinal bars may have been initiated as a diffuse sheet during, or immediately after, flood stage. During flood stage the stream was strong enough to move even the coarsest clasts. These were deposited when the flow reduced and the morphology of the bed surface (the presence of riffles and pools that were not big enough to influence the clast's movement during flood stage) tended to influence them. The clasts acted as a trap for other clasts, and a bar developed with crude horizontal stratification and imbricate clasts. These characteristics, together with the absence of crossstratification, suggest that most of the gravel tended to move during high flow stage in sheets, and not by avalanching on the lee sides or lateral flanks of bars (Eynon \& Walker, 1974).

During reduced flow, bar movement stopped and its upper surface may even have emerged. Flow was then only active along lateral channels and sometimes also along small cross-over channels on top of the bars. These channels may have been filled with sand, which helps to distinguish individual bars (Fig. 3).

The fact that clasts inside the bars are in contact with each other, that there is little or no matrix (openwork gravels) and that there is often an alternation of different clast sizes, may be the result of high- and low-discharge events (Smith, 1974) During high flows, sands were carried in suspension above gravels. As flow decreased, finer gravels were deposited above the larger ones, and finally sand was deposited, filling pores in the gravels but not reaching the lowest gravel beds. This process produced a lower openwork gravel and an upper, sand-filled gravel.

Clast pavements (Fig. 3B), one clast thick, may be found between two longitudinal bars. They may be the result of flow increases, not strong enough to move the clasts but capable of sweeping the sand matrix from around the clasts, producing a lag between two 
successive bars, but may also occur after a single flood. Flood gravels tend to have a high matrix content and the falling-stage flow washes out the matrix to give lag sheets.

Upstream imbrication is common inside our longitudinal bars, giving a reliable indicator of palaeocurrents, particularly in the case of larger discoidal clasts (Fig. 4). These larger clasts show a minimum deviation from the trend of the main channel because they are oriented during major floods and resist movement during lower-stage flooding, when normally deviations occur from the general trend (Bluck, 1979). Discoidal clasts have here a preferential tranverse imbrication (in the sense of Harms et al., 1975, p. 137), but cylindrical clasts have a preferential parallel imbrication. An explanation has been offered by Rust (1972a), who suggested that high concentrations of clasts (as in our Buntsandstein), and high velocities favour long-axis orientation parallel to the current.

The accretionary deposits (Fig. 2C) that we find laterally and on top of longitudinal bars (Figs 3 and $5 \mathrm{~A})$ may be the modification of these bars during waning flow. Because of the decrease in flow, or perhaps when bars had reached a certain height in relation to the depth of water, few or no clasts could be moved over the bar. Nevertheless, flow was strong enough to move clasts laterally along the bar margins. Similar processes have been described by Costello \& Walker (1972) and Smith (1974). According to Bluck (1976) this process is mostly confined to the bar heads (upstream areas, coarse grained, normally with imbricate clasts).

When lateral accretionary processes continued, lateral foresets developed, dipping towards the lateral channels at an angle less than $90^{\circ}$ to the general trend as shown by imbrication inside the foresets (Fig. 3). This deviation between structures indicating the flow direction and the bar accretion direction has been recorded by Bluck (1979) in the Tulla River (Scotland).

Vertical accretion occurred on the tops of bars, simultaneously with lateral accretion (Fig. 3). Vertical accretion was always minor in comparison with lateral accretion and was probably controlled by the depth of water. Thus foresets are thinner on top of bars and become thicker laterally and downwards with a maximum towards the base. Sandstone drapes (Figs 3 and $5 \mathrm{~A}$ ) between foresets and alternations of different grainsize foresets may represent changes in flow stage.

Channel deposits (Fig. 2D) may have formed laterally to longitudinal bars. Channel deposits may pass into bars by transition into lateral accretionary deposits (Fig. 3). Sometimes a multi-storey pattern of channels developed (Fig. 2D), with channels cutting into each other both vertically and laterally. This is very characteristic of braided streams (Williams \& Rust, 1969; Costello \& Walker, 1972). Gravel lag has been recorded in many channels, and may be the result of winnowing of earlier deposits when cut into by a lateral channel.

Mud or fine sand beds that we have found inside multi-storey channels may be the result of the settling of fine sediments in periodically abandoned channels. Channels were sometimes filled with massive gravel (Fig. 2D), making it difficult to recognize whether they have filled during one or more events, but they were more often filled with sets of cross-bedded gravels and coarse sandstones, sub-parallel to the channel margins. These planar cross-bedded gravels and sandstones may be the result of lateral accretion of longitudinal bars, downfilling side channels during the waning stage. This has been recorded in both ancient and recent braided streams by McGowen \& Groat (197i) and Fraser \& Fishbaugh (1980). Large channels filled with large trough cross-sets of gravel (Figs 2D, 6 and 7) may be the result of bankfull discharge, when the entire valley has acted as a channel (Fraser \& Fishbaugh, 1980). Some channels were filled with gravels in the lower part (Fig. 7), the grain size then decreasing laterally, passing into gravelly sandstones (Fig. 7). This may be due to the different stream power in the channel as the depth of water varied. The currents may be powerful enough to move gravels along the channel bed, but only competent to move finer sediments in shallower water.

The planar tabular cross-stratified conglomerates (Figs $2 \mathrm{~B}$ and $5 \mathrm{~B}$ ) that are rare in our sequences may be due to migration of transverse bars. Similar transverse bars have been described in present-day braided streams (Ore, 1964; Rust, 1972b). According to Hein \& Walker (1977) these bars, with well-defined foresets, reflect a lower water and sediment discharge than the longitudinal bars.

Flat- or low-angle-bedded sandstones (Fig. 2F) that can be followed laterally across tens of metres and over different deposits (they may be found simultaneously over several channels or longitudinal or transverse bars) may have been produced during high flood stage, when water was not confined to incised channels. Flood water may then have spread from the main channels across bar surfaces and abandoned channel deposits, flowing with high velocity across all sediments and forming flat- or low-angle-bedded sandstones. Similar processes have been described for 
upper and middle fan areas formed by braided streams (Boothroyd \& Ashley, 1975).

Local trough cross-bedded sandstones (Fig. 5A, B) on top of low-angle or flat-bedded sandstones may be due to a decrease in energy, causing sands to move as megaripples and forming trough cross-bedded sandstones.

Fine-grained sediments (sometimes with biotur- bation) are very rare in our sediments. As Costello \& Walker (1972) pointed out, in a system where coarse sediments are predominant, deposition of fine material will only occur in small, specially sheltered areas on the floodplain. There were probably not many of these small areas in our system. Nevertheless, some large mud or muddy sandstone clasts are associated with large scoured surfaces which points to the former
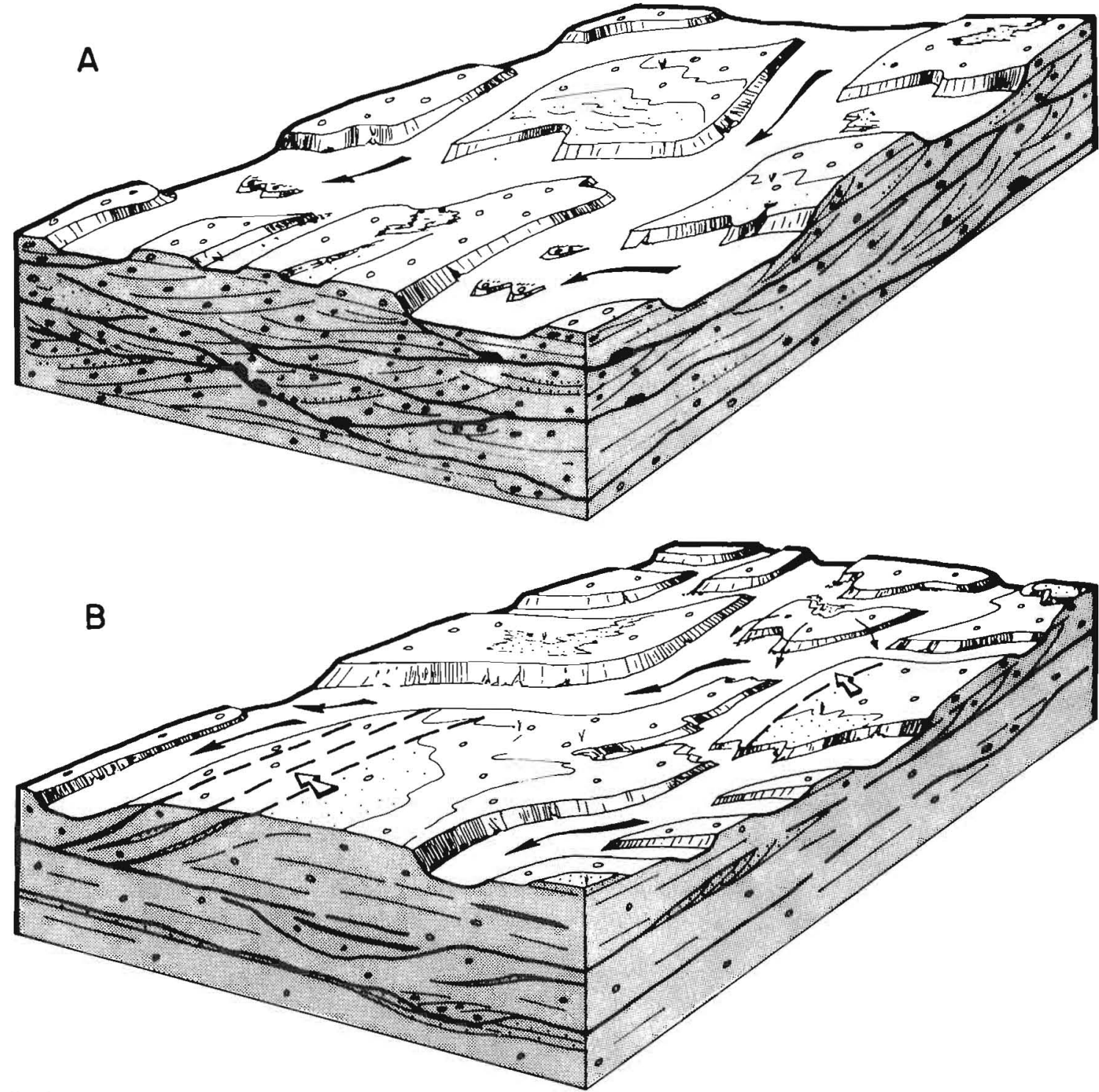

Fig. 8. (A) Lower cycle block diagram. Smaller bars. Higher preservation rate of channel fill. Preservation of some convex-upward tops of bars. Periodic large scoured surfaces. Very rare overbank deposits (see also Fig. 6). (B) Upper cycle block diagram. Larger longitudinal bars with lateral growth. Higher channel sinuosity. Preservation of convex-upward top of bars. Periodic large scoured surfaces. Very rare overbank deposits (see also Fig. 3A). 
presence of some of these fine-grained units with a very low preservation rate.

\section{CONCLUSIONS}

The main characteristics of conglomerates that form the basal Buntsandstein in the Iberian Ranges (Fig. 1) indicate relatively high-energy streams, with prevalent bedload transport. They are thick gravel deposits and have very few sandstone beds and rare mudstone beds.

According to Bluck (1979), the gravel-to-sand ratio is the most important factor controlling the structure of sediments like these. The ratio has probably influenced the different bedforms in our sediments, producing a complex pattern of bars and channels with very few, or no, overbank deposits.

The high bedload to suspension-load ratio may have favoured the rounding of gravels that can be seen in these sediments. This fact has been pointed out by McGowen \& Groat (197l) for the Van Horn Sandstone. However, many clasts must be second cycle, as has been previously shown (Ramos, 1979; Sopeña, 1979), and this also results in a high rounding. These gravels were mainly arranged internally as relatively simple units. They were formed in bars and channels of low-sinuosity braided stream systems.

Two big cycles may be seen in the complete sedimentary sequence of these lower Buntsandstein conglomerates. They differ in the frequency, distribution and preservation of different depositional units, corresponding to different physiographic models (Fig. $8 \mathrm{~A}, \mathrm{~B})$. The change in sedimentation may be related to fluvial system pattern change, due to the tectonic movements that occurred in the basin during Buntsandstein times.

The lower cycle (Fig. 8A) was mainly formed by smaller channels and bars than the upper cycle. Fast migration and fill of channels may have been due to quick and frequent fluctuations, together with slightly higher slope. These features may also have been responsible for the very low preservation rate and for the modifications and scoured surfaces on top of the few bars that have been preserved.

The upper cycle (Fig. 8B) is mainly made up of longitudinal bars with not very complex internal organization. The lateral growth that can be seen indicates higher stability for those bars, together with higher channel sinuosity. According to Smith (1974), these features are characteristic of gravelly streams with distinct high and low discharges.
Nevertheless, the preservation of entire bed forms (e.g. convex-upward tops of bars) together with the conglomerate thickness indicate generally high subsidence related to the vertical movements that have been described above.

No major vertical pattern of grain-size change has been recorded in these conglomerates. The most important vertical features of the two cycles are the periodic large scoured surfaces, each 10-15 m deep, that can be followed laterally across hundreds of metres. They have big blocks from the underlying sediments and may be related to periodic tectonic reactivation.

\section{ACKNOWLEDGMENT}

We are very grateful to Dr P. F. Friend (University of Cambridge) for reading the manuscript, patiently correcting the English, and for useful comments to improve it.

\section{REFERENCES}

BLuCK, B.J. (1976) Sedimentation in some Scottish rivers of low sinuosity. Trans R. Soc. Edinb. 69, 425-456.

Bluck, B.J. (1979) Structure of coarse grained braided stream alluvium. Trans. R. Soc. Edinb. 70, 181-221.

Boorhroyd, J.C. \& Ashley, G.M. (1975) Process, bar morphology and sedimentary structures on braided outwash fans, North-eastern Gulf of Alaska. In: Glaciofuvial and Glaciolacustraine Sedimentation (Ed. by A.V. Jopling and B.C. McDonald). Spec. Publs Soc. econ. Paleont. Miner., Tulsa, 23, 193-222.

Costello, W.R. \& Walker, R.G. (1972) Pleistocene sedimentology: Credit River, Southern Ontario: a new component of the braided river model J. sedim. Petrol. 42, 389-400.

EynON, G. \& WALKeR, R.G. (1974) Facies relationships in Pleistocene outwash gravels, Southern Ontario: a model for bar growth in braided rivers. Sedimentology, 21, 43-70.

Fraser, G.S. \& Fishbaugh, D.A. (1980) Sedimentary structures of the late Wisconsian terraces along the Wabash River. Great Lake Section Spec. Paper. Soc. econ. Petrol. Mineral Field Trip Guidebk pp. 59-78.

Harms, J.C., Southard, J.B., Spearing, D.R. \& Walker, R.G. (1975) Depositional environments as interpreted from primary sedimentary structures and stratification sequences. Soc. econ. Palcont. Mineral. Short Course, Dallas, 2, $161 \mathrm{pp}$.

Hein, F.J. \& WALKer, R.G. (1977) Bar evolution and development of stratification in the gravelly, braided Kicking Horse River, British Columbia. Can. J. Earth Sci. $14,562-570$.

Leopold, L.B. \& Wolman, M.G. (1957) River channel patterns: braided, meandering and straight. Prof. pap. U.S. geol. Surv. 282-B, 85 pp.

MCGowen, J.H. \& GronT, C.G. (197I) Van Horn Sandstone, West Texas: an alluvial fan model for mineral 
exploration. Rep. Invest. Bur. econ. Geol. Univ. Texas, 72, 57 pp.

ORE, H.T. (1964) Some criteria for recognition of braided stream deposits. Wyoming Univ. Dept. Geol. Contr. Geol. 3, 1-14.

Ramos, A. (1979) Estratigrafía y paleogeografía del Pérmico y Triásico al oeste de Molina de Aragón. Seminarios de Estratigrafia, Serie Monografias, 6, $313 \mathrm{pp}$.

Rust, B.R. (1972a) Structure and process in a braided river. Sedimentology, 18, 22l-245.

Rusr, B.R. (1972b) Pebble orientation in fluviatile sediments. J. sedim. Petrol. 42, 384-388.

Rust, B.R. (1978) Depositional models for braided alluvium.
In: Fluvial Sedimentology (Ed. by A.D. Miall). Mem. Can. Soc. Perrol. Geol., Calgary, 5, 605-625.

SmIrH, N.D. (1974) Sedimentology and bar formation in the Upper Kicking Horse River, a braided outwash stream. $J$. Geol. 82, 205-224.

SOPEÑA, A. (1979) Estratigrafía del Pérmico y Triásico del noroeste de la provincia de Guadalajara. Seminarios de Estratigrafia, Serie Monografias, 5, 329 pp.

Virgili, C., Sopeña, A., Ramos, A., Hernando, S. \& Arche, A. (1980) El Pérmico en España. Revista Española de Micropaleontologia, XII, 2, 255-262.

Williams, P.F. \& Rust, B.R. (1969) The sedimentology of a braided river. J. sedim. Petrol. 39, 649-679. 